
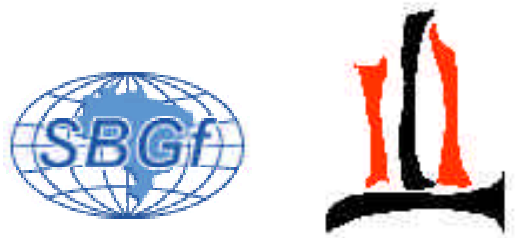

São Paulo 2004

\title{
Scaling Relationships between Earthquake Magnitude and Surface Fault Rupture Dimensions for Intraplate Earthquakes in Stable Continental Regions and Their Implications
}

Vasile MARZA*), Takato NAKAYOSHI \& Dhébora VENTURA

Seismological Observatory, University of Brasilia, CP 04598, Campus Universitario, Brasilia-DF, Brazil, CEP70900-900

E-mail:<marza@unb.br>

*) On leave from Seismological Laboratory, National Institute (R\&D) for Earth Physics, Bucharest, Romania

Copyright 2004, SBGf - Sociedade Brasileira de Geofísica

Este texto foi preparado para a apresentação no I Simpósio de Geofísica da Sociedade Brasileira de Geofisica, São Paulo, 26-28 de setembro de 2004. Seu conteúdo foi revisado pela Comissão Tecno-científica do I SR-SBGf mas não necessariamente representa a opinião da SBGf ou de seus associados. E proibida a reprodução total ou parcial deste material para propósitos comerciais sem prévia autorização da SBGf.

\section{Summary}

We have developed new and revised scaling relations between moment magnitude $\left(\mathrm{M}_{\mathrm{w}}\right)$ and documented surface rupture length $(S R L)$ and maximum vertical offset $\left(u^{v}\right)$ specific for intraplate earthquakes occurring in stable continental regions, using the ordinary least-squares linear regression procedure based on an updated and amended data set. The results of our linear regressions are compared with similar relations both for interplate and intraplate earthquakes and some inferences regarding the Brazilian intraplate seismicity are undertaken, as well.

\section{Introduction}

Despite the progress made since the pioneering works on intraplate seismicity during the '70s (e.g., Sbar \& Sykes 1973; Sykes 1978; etc) and especially during the last fifteen-twenty years, when a concerted effort was devoted to the better understanding of tectonics, physics and hazard of intraplate earthquakes (Nuttli 1983; Hinze et al. 1988; Talwani \& Rajendran 1991; Schneider (Ed.) 1994; Coblentz \& Richardson 1995; Johnston 1996a,b,c; Rajendran \& Rajendran 1999a,b; Bakun \& McGarr 2002; etc) because it was realized the great gap between the perceived and potential hazard of the intraplate earthquakes (viz. Seeber 2002; Crone et al. 2003), yet, the realm of intraplate seismicity is puzzling and challenging the seismologists (e.g., Ellis et al. 2001). The issue turns out to be hardly tackled, as the amount of data on intraplate seismicity is much scarcer than for other tectonic environments, especially because of the very low rate of intraplate seismicity.

The similarities and/or differences between interplate and intraplate earthquakes can provide important information about the seismogenesis, physical source mechanism or occurrence processes that govern their behaviour. On the other hand, relations between (moment) magnitude (or seismic moment) and a source length scale [e.g., surface rupture length $(S R L)$, square root of rupture area $\left(A^{1 / 2}\right)$, maximum vertical offset $\left(u^{v}\right)$ etc] for earthquakes have long been employed in seismology as valuable gross scaling relations between static source parameters (viz. Kanamori \& Rivera, 2004).
The purpose of this paper is to develop new and revised of such relationships, particularly for surface rupture length $(S R L)$ and maximum vertical offset $\left(u^{v}\right)$, i.e. $\log _{10}(S R L) \sim M_{w}$ and $\log _{10}\left(u^{v}\right) \sim M_{w}$, specifically for intraplate earthquakes, to compare them with similar relationships derived from interplate events and to try to provide some insights on the intraplate earthquake physics.

\section{Data Description}

Before to make a presentation of the data we find useful to make some comments on the taxonomy of earthquakes/seismicity occurring in plate-interior settings. One distinguishes between two subsets of plate-interior earthquakes, events occurring in continental active regions and events occurring in stable continental regions (SCRs) [see details of definition in Johnston 1989; Johnston \& Kanter 1990; or Kanter, 1994]. Furthermore, to be more flexible we use interchangeably the terms intraplate and SCR, yet when we use the term intraplate earthquake, it refers mainly to SCR earthquake, if it is not otherwise specified.

As it was already mentioned, the data concerning the SCR events are very limited; orders of size lower than boundary-plate or active continental regions events. Regarding documented surface (earthquake) ruptures in SCR, by 1990 world-wide only ten known surface rupture have been catalogued (Johnston \& Bullard, 1990; Adams et al. 1991; Johnston 1991, 1992). To date, only one more event (Killari (Latur), India, 1993 earthquake) has joined the set, making the total to rise to eleven historical SCR earthquakes with documented surface rupture (e.g., Crone et al. 2003).

Our input data are summarized in Table 1, which is principally based on data compiled by Crone et al. (2003), to which we did some light corrections, changes or amendments. [The largest SCR earthquake of instrumental era, i.e., 2001 Bhuj, India, $M_{w}=7.6$ event, triggered an obvious and enormous interest and left no unambiguous evidence for a direct surface rupture, highly anomalous for an earthquakes of its size. Hence, for the sake of wholeness and comparative discussion we included (in Table 1, item \#12) the 2001 Bhuj, India, event, although its source parameters are not utilized for regression purposes, yet it provides useful information for comparison and examination purposes].

The primary data used in this work are obtained from published results, furthermore we have crosschecked the accuracy and reliability of data and we have adopted the most certain ones in order to get an as much as 
homogeneous and consistent data set. As regard the magnitude quantification we adopted the moment magnitude scale, particularly based on the Harvard's CMT Solutions wherever possible [ $\left.\mathrm{M}_{\mathrm{w}}(\mathrm{HRV})\right]$. For events what are not present in Harvard Catalogue we have used Johnston (1996a) data or methodology for assessing the $M_{w}$ values (NB: for those events that have no genuine HRV determinations we used italic characters/digits to itemize them in Table 1).

The SRL data (last but one column in Table1) are mainly from Crone et al. (2003) and showed by common case digits, as contrasted with others to be discussed next. The SRL in italics (events \#5 and \#10) are amended values based on original reports (ISC 1973 p.273; and respectively, Adams et al. 1991, p.617). The 1993 Killari (Latur), India, event (item \#11, Table 1) deserves a particular discussion; it is quoted (in previous works) with a $S R L$ value of $0.5 \mathrm{~km}$, which obviously it is not realistic for a magnitude 6.2 earthquake. Hence in order to make most of it (otherwise it would be an outlier), in the light of the scarcity of surface rupture events, we resolved to infer its rupture length based on graphical inspection of the aftershock spatial distribution studied by Rajendran \& Rajendran (1999a), resulting a value of $12.5 \mathrm{~km}$, in not too bad agreement with the provisional value of about 10 $\mathrm{km}$ envisaged by Seeber (1994). The SRL and maximum vertical offset for 2001 Bhuj earthquake (item \#12 in Table
1) were inferred by our graphical inspection from Negishi et al. (2002) aftershock location and from Gupta et al. (2001) estimation, respectively. The geographical distribution of the events contained in Table 1 is presented in Figure 1.

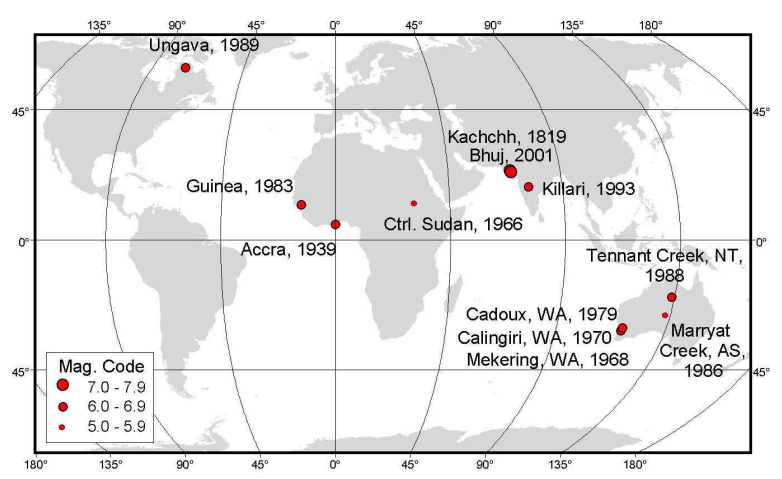

Fig. 1. Geographical Distribution of Documented SCR Surface Faulting (see Table 1) Used in This Note (Robinson Projection)

Table 1

Source Parameters for SCR Earthquakes with Documented Surface Ruptures (Main Source: Crone et al. 2003)

\begin{tabular}{|c|c|c|c|c|c|c|c|c|}
\hline \# & $\begin{array}{l}\text { Location } \\
\text { and Name }\end{array}$ & Date & $\begin{array}{l}\text { Epicentre } \\
\text { Coordinates }\end{array}$ & $\begin{array}{l}\text { Depth } \\
(\mathrm{km})\end{array}$ & $\begin{array}{c}\mathbf{M}_{\mathbf{w}} \\
(\mathrm{HRV})\end{array}$ & $\begin{array}{c}\text { Faulting } \\
\text { Style }\end{array}$ & $\begin{array}{l}\text { SRL } \\
(\mathrm{km})\end{array}$ & $\begin{array}{l}\text { Max. Vert. } \\
\text { Offset (m) }\end{array}$ \\
\hline 1 & Allah Bund, Kachchh (Kutch), India & $1819 / 06 / 16$ & $24.0 \mathrm{~N} ; 70.0 \mathrm{E}$ & 15 & 7.5 & Unk.(R?) & 90 & 9 \\
\hline 2 & Accra, Ghana, Africa & $1939 / 06 / 22$ & $5.2 \mathrm{~N} ; \quad 0.1 \mathrm{~W}$ & 14 & 6.5 & SS? & 17 & 0.46 \\
\hline 3 & Central. Sudan, Africa & $1966 / 10 / 09$ & $12.6 \mathrm{~N} ; 30.8 \mathrm{E}$ & 10 & 5.1 & SS & 6 & 0 \\
\hline 4 & Mekering, WA, Australia & $1968 / 10 / 14$ & $31.6 \mathrm{~S} ; 117.0 \mathrm{E}$ & 3 & 6.6 & SS-R & 37 & 3.5 \\
\hline 5 & Calingiri, WA, Australia & $1970 / 03 / 10$ & $31.0 \mathrm{~S} ; 116.5 \mathrm{E}$ & 5 & 5.7 & SS-R & 4 & 0.4 \\
\hline 6 & Cadoux, WA, Australia & $1979 / 06 / 02$ & $30.7 \mathrm{~S} ; 117.2 \mathrm{E}$ & 3 & 6.3 & SS-R & 28 & 1.4 \\
\hline 7 & Guinea, West Africa & $1983 / 12 / 22$ & $12.0 \mathrm{~N} ; 13.5 \mathrm{~W}$ & 8 & 6.3 & SS & 9.4 & 0.13 \\
\hline 8 & Marryat Creek, AS, Australia & $1986 / 03 / 30$ & $26.2 S ; 132.8 \mathrm{E}$ & 3 & 5.7 & R-SS & 13 & 0.9 \\
\hline 9 & Tennant Creek, NT, Australia & $1988 / 01 / 22$ & 19.9S; $134.0 \mathrm{E}$ & 4.5 & $6.7^{\pi}$ & $\mathrm{R}$ & $32^{\pi}$ & 1.8 \\
\hline 10 & Ungava, Northern Canada & $1989 / 12 / 25$ & $60.1 \mathrm{~N} ; 73.6 \mathrm{~W}$ & 2.5 & 6.0 & R-SS & 8.5 & 1.8 \\
\hline 11 & Killari (Latur), India & $1993 / 09 / 29$ & $18.1 \mathrm{~N} ; 76.5 \mathrm{E}$ & 5 & 6.2 & $\mathrm{R}$ & 12.5 & 0.8 \\
\hline 12 & Bhuj (Republic Day), Gujarat, India & $2001 / 01 / 26$ & $23.4 N ; 70.3 E$ & 18 & 7.6 & $R$-SS & (90) & 8.5 \\
\hline
\end{tabular}

Notes: magnitude values in italics are not genuine Harvard determinations (see the text for details); ${ }^{\text {" }}$ denotes a cumulative $S R L$ and magnitude; SRL values in italics are corrected or amended relative to main source; faulting types: SS strike-slip, R - reverse; though yet no unequivocal evidence for surface rupture was reported for item \#12, it is included (but not used in regressions) for the sake of completeness and comparisons.

\section{Regression Model}

There are various regression models for calculating the relationship between any pair of variables, as: linear, non-linear etc., but commonly most studies use the simple linear regression such as the ordinary leastsquares model. However, the ordinary least-squares model produce a solution that minimize the error in 
predicting the dependent variable and also it does not score poorer then the weighted least-squares model (Wells \& Coppersmith 1994). Besides this, our input data which sum only 10 observational data points dose not justify the use of sophisticated regression models. Under the circumstances, our ordinary least-squares regression analyses involve linear regression of $\log _{10}$ of surface rupture length (SRL) and/or maximum vertical offset $\left(u^{v}\right)$ versus moment magnitude $\mathrm{M}_{\mathrm{w}}$. The empirical relations have the form $\log _{10}(y)=a+b * x$, where $x$ is the independent variable (that is, $M_{w}$ ) and $y$ is the dependent one (SRL or $\left.u^{v}\right)$.

\section{Regression Results}

The equations (1) and (2) summarize the regression descriptors derived by fitting the data of Table 1 .

$$
\log _{10}(S R L(\mathrm{~km}))=0.50 * \mathrm{M}_{\mathrm{w}}-1.86
$$

with 10 data points used, correlation coefficient $r=0.78$ and $\sigma=0.032$.

$$
\log _{10}\left(u^{v}(m)\right)=0.48 * M_{w}-2.80
$$

with 7 data points used, correlation coefficient $r=0.79$ and $\sigma=0.033$.

The figures 2 and 3 show the data points used and the regression lines.

We are aware of the inherently very limited database used in our study, hence a thorough (quantitative) statistical significance analysis of the regression results is unwarranted, but we will try to make some qualitative inferences in this sense in next section.

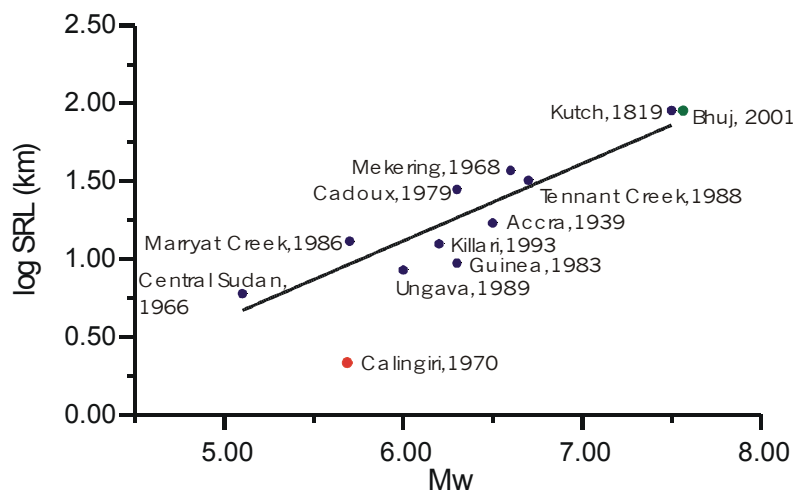

Fig. 2. Regression of magnitude $\left(\mathrm{M}_{\mathrm{w}}\right)$ on $S R L(\mathrm{~km})$. Blue points stand for used data; the red one depicts an outlier

(Calingiri, 1970 event) and the green one illustrates for discussion purpose the Bhuj, 2001 earthquake.

\section{Discussion and Conclusion}

First, the scaling relation (1) and its Fig. 2 are based on 10 data points (blue dots) shows an acceptable statistical significance and we judge that excluding the Calingiri datum (red point) is warranted, it being a clear outlier. Moreover, as a check, the Bhuj datum (green point) matches very well the regression result. For comparison with other similar empirical regressions we summarize below some of them: (i) $\log _{10}(S R L)=0.74 * \mathrm{M}_{\mathrm{w}}-3.43$ [J; SCRs],

(ii) $\log _{10}(S R L)=0.69 * \mathrm{M}_{\mathrm{w}}-3.22$ [W\&C; world-wide],

(iii) $\log _{10}(S R L)=0.51 * \mathrm{M}_{\mathrm{w}}-1.85$ [P\&P; Aegean region], (iva) $\log _{10}(S R L)=0.50 * \mathrm{M}_{\mathrm{w}}-2.19$ [D\&R; N. Z, reg.; $\mathrm{M}<6$ ], (ivb) $\log _{10}(S R L)=0.63 * \mathrm{M}_{\mathrm{w}}-2.89$ [D\&R; N. Z. reg.; $M$ 6],

where: $\mathrm{J}=$ Johnston 1991; W\&C = Wells \& Coppersmith 1994; P\&P = Papazachos \& Papazachos 1997; D\&R = Dowrick \& Rhoades 2004; N.Z. stands for New Zealand, and NZ data refer to subsurface rupture lengths.

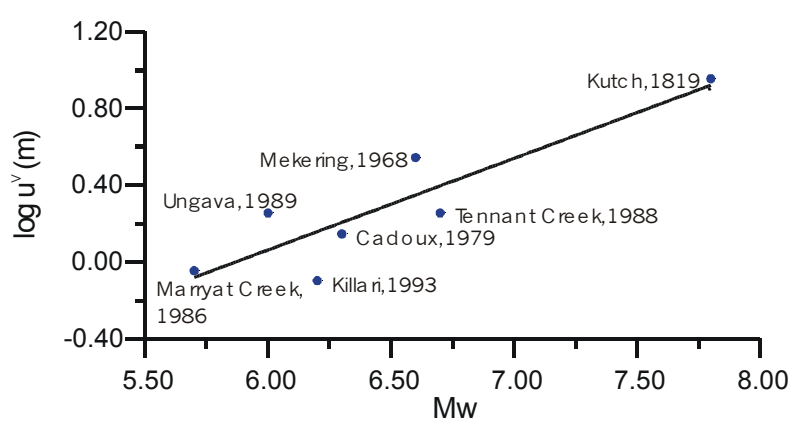

Fig. 3. Regression of magnitude $\left(M_{w}\right)$ on maximum vertical offset $\left(u^{v}(\mathrm{~m})\right)$

We may note that eq. (iii) is surprisingly close to our eq. (1) notwithstanding the different tectonic setting, and (iva) has similar slope but different intercept, while the others have different slopes. From theoretical and empirical source-parameter dimensional analysis based on the well established: $\log _{10}\left[\right.$ Rupture Area $\left.\left(\mathrm{km}^{2}\right)\right]=\mathbf{M}-$ 4 (viz. Kanamori \& Anderson 1975; Wyss, 1979; etc) it would results for $\log _{10}(S R L)$ vs. $\mathrm{M}_{\mathrm{w}}$ a slope of $1 / 2$ Hence, our relation (1) agrees very well with theoretical and empirical expectations. Table 2 presents a synopsis of predictions of $S R L$ according to scaling relations discussed above.

Table 2. Predictions of $S R L(\mathrm{~km})$

\begin{tabular}{|c|c|c|c|c|c|}
\hline \multirow{2}{*}{$\mathrm{M}_{\mathrm{w}}$} & \multicolumn{4}{|c|}{ According to relations above considered } \\
\cline { 2 - 6 } & (i) & (ii) & (iii) & (iva\&b) & This work \\
\hline 5 & 2 & 2 & 5 & 2 & 4 \\
\hline 6 & 10 & 8 & 16 & 8 & 14 \\
\hline 7 & 56 & 41 & 52 & 33 & 44 \\
\hline 8 & 309 & 200 & 170 & 141 & 138 \\
\hline
\end{tabular}

Table 2 tells alone about affinity, conflict or confidence of the predictions of various scaling relations discussed. Notwithstanding our small data set, which precludes a robust generalization, however we may note in Fig. 2 that all Australian events (except Calingiri, which is anyway an outlier) are laying above the regression line, what could be a geographical feature in manifestation of SCR seismicity.

As regard our relation (2) between maximum vertical offset and magnitude offset there are less reported results in literature, e.g.: $\log _{10}(M D(\mathrm{~m}))=0.5 * \mathrm{M}_{\mathrm{w}}-3.04$ (after $\mathrm{D} \& \mathrm{R}$, above, where $M D$ is maximum displacement on fault) or $\log _{10}(M D(m))=0.82 * \mathrm{M}_{\mathrm{w}}-5.46$ (after W\&C 
above), and we leave room to the reader to make his mind.

Last, touching the Brazilian issues, we may infer using eq. (1) the fault length of the 1955 Mato Grosso event, $m_{b}$ $=6.6$ (cf., Berrocal et al. 1984) or converted to $M_{w}=6.7$, would be $31 \mathrm{~km}$; or for the same event considering the reappraised value of $\mathrm{m}_{\mathrm{b}}=6.2$ (cf. Assumpção 1998)[converted to $M_{w}=6.2$ ] would give in turn a $S R L$ of $17 \mathrm{~km}$ (the average of the two estimates is $24 \mathrm{~km}$ ). And the maximum offset would be $2.6 \mathrm{~m}$, or respectively $1.5 \mathrm{~m}$ (an average of $\approx 2 \mathrm{~m}$ ) [NB: the 1955 Mato Grosso event is the largest observed SCR earthquake in Brazil].

\section{References}

Adams, J., Wetmiller, R.J., Hasegawa, H.S. \& Drysdale, J., 1991. The First Surface Faulting from a Historical Intraplate Earthquake in North America, Nature 352: 617-618.

Assumpção, M., 1998. Sismotectônica y esfuerzos em Brasil (Seismotectonics and stresses in Brazil), Física de la Tierra $\mathrm{n}^{\circ} \mathbf{1 0}$ 149-166 (in Spanish).

Bakun, W.H. \& McGarr, A., 2002, Differences in Attenuation among the Stable Continental Regions, Geophys. Res. Lett. 29, doi:10.1029/2002GL015457.

Berrocal, J., Assumpção, M., Antezana, R., Dias Neto, C.M., Ortega, R., França, H. \& Veloso, J.A.V., 1984. Sismicidade do Brasil (Seismicity of Brazil), IAG-USP \& CNEN, São Paulo, SP , Brazil, 320 pp + 4 maps (in Portuguese).

Coblentz, D.D. \& Richardson, R.M., 1988. Statistical Trends in the Intraplate Stress Field, J. Geophys. Res. 100: 20,245-20,255.

Crone, A. J., De Martini, P. M., Machette, M .N., Okumura, K. \& Prescott, J. R., 2003. Paleoseismicity of Two Historically Quiescent Faults in Australia: Implications for Fault Behaviour in Stable Continental Regions, Bull. Seism. Soc. Am. 95: 1913-1934.

Dowrick, D.J. \& Rhoades, D.A., 2004. Relations between Earthquake Magnitude and Fault Rupture Dimensions: How Regionally Variable They Are?, Bull. Seism. Soc. Am. 94: 776-788.

Ellis, M., Gomberg, J. \& Schweig, E., 2001. Indian Earthquake May Serve as Analog for New Madrid Earthqaukes, EOS/Trans. A.G.U. 82:345 \& 350 .

Gupta, H.K., Purnachandra Rao, N., Rastogi, B.K. \& Sarkar, D., 2001. The Deadliest Intraplate Earthquake, Science 291: 2101-2102.

Hinze, W.J., Braile, L.W., Keller, G.R. \& Lidiak, E.G., 1988. Models for Midcontinent Tectonism: An Update, Rew. Geophys. 26: 699-717.

ISC, 1970. Regional Catalogue of Earthquakes, v. 7, n. 1, 1970 JanuaryJune, International Seismological Centre, Edinburgh, Scotland, UK.

Johnston, A. C., 1989. The Seismicity of 'Stable ContinentaL Interiors', in Gregersen, S. \& Basham, P. M. (Eds), Earthquakes at North-Atlantic Passive Margins: Neotectonics and Postglacial Rebound, Kluwer, Acad. Publ., Dordrecht, The Netherlands, 299-327.

Johnston, A. C., 1991. Surface Rupture in Stable Continental Regions, EOS/Trans. A.G.U. 72:489.

Johnston, A. C., 1992. Intraplate Not Always Stable, Nature 355: 213-214.

Johnston, A.C., 1996a. Seismic Moment Assessment of Earthquakes in Stable Continental Regions - I. Instrummental Seismicity, Geophys. J. Int. 124: 381-414.

Johnston, A.C., 1996b. Seismic Moment Assessment of Earthquakes in Stable Continental Regions - II. Historical Seismicity, Geophys. J. Int. 125: $639-678$.
Johnston, A.C., 1996c. Seismic Moment Assessment of Earthquakes in Stable Continental Regions - III. New Madrid 1811-1812, Charleston 1886 and Lisbon 1755, Geophys. J. Int. 126: 314-344.

Johnston, A. C. \& Bullard, T., 1990. Seismological Res. Lett. 61:152-153.

Johnston, A. C., \& Kanter, L. S., 1990. Earthquakes in Stable Continental Crust, Scientific American 262: 42-49.

Kanamori, H. \& Rivera, L., 2004. Static and Dynamic Scaling Relations for Earthquakes and Their Implications for Rupture Speed and Stress Drop, Bull. Seism. Soc. Am. 94: 314-319.

Kanamori, H. \& Anderson D.L., 1975. Theoretical Basis of Some Empirical Relations in Seismology, Bull. Seism. Soc. Am. 65: 1073-1095.

Kanter, L.R., 1994. Tectonic Implication of Stable Continental Crust, in Schneider, J.F. (Ed.) The Earthquakes of Stable Continental Regions: Assessment of Large Earthquake Potential, EPRI Rpt. TR-102261, Ch. 2, p.2-1-2-98, Electric Power Res. Inst., Palo Alto, CA.

Negishi, H., Mori, J., Sato, T., Singh, R., Kumar, S. \& Hirata, N., 2002 Size and Orientation of the Fault Plane for the 2001 Gujarat, India Earthquake $\left(M_{w} 7.7\right)$ from Aftershock Observations: A High Stress Drop Event, Geophys. Res. Lett. 29, doi:10.1029/2002GL015280.

Nuttli,O.W., 1983. Average Seismic Source-Parameter Relations for MidPlate Earthquakes, Bull. Seism. Soc. Am. 73: 519-535

Papazachos, B., \& Papazachos, C., 1997. The Earthquakes of Greece, Ziti \& Co., Thessaloniki, Greece, pp.304

Rajendran, K. \& Rajendran, C.P., 1999a. Seismogenesis in the Stable Continental Interiors: an Appraisal Based on Two Examples from India, Tectonophysics 305: 355-370.

Rajendran, K. \& Rajendran, C.P 1999b Geological Investigations at Killari and Ter, Central Idia and Implications for Paleoseismicity in the Shied Region, Tectonophysics 308: 67-81.

Sbar, M.L. \& Sykes, L.R., 1973, Contemporary Compressive Stress and Seismicity of Eastern North America: An Example of Intraplate Tectonics, Geol. Soc. Am. Bull. 84: 1,861-1,882.

Schneider, J.F. (Ed.), 1994. The Earthquakes of Stable Continental Regions: Assessment of Large Earthquake Potential, EPRI Rpt. TR102261, Electric Power Res. Inst., Palo Alto, CA.

Seeber, L., 1994. Killari: The Quake that Shook the World, New Scientist 142: $25-29$.

Seeber, L., 2002. Mechanical Pollution, Seismol. Res. Lett. 73: 315-317.

Sykes, L.R., 1978. Intraplate Seismicity, Reactivation of Preexisting Zones of Weakness, Alkaline Magmatism, and Other Tectonism Postdating Continental Fragmentation, Rev. Geophys. Space Phys. 16: 621-688.

Talwani, P. \& Rajendran, K., 1991. Some Seismological and Geometric Features of Intraplate Earthquakes, Tectonophysics 186: 19-41.

Wells, D.L. \& Coppersmith, K.J., 1994. New Empirical Relations among Magnitude, Rupture Length, Rupture Width, Rupture Area, and Surface Displacement, Bull. Seism. Soc. Am. 84: 974-1002.

Wyss, M., 1979. Estimating Maximum Expectable Magnitude of Earthquakes from Fault Dimension, Geology 7: 336-340. Dimension, Geology 7: 336-340. 